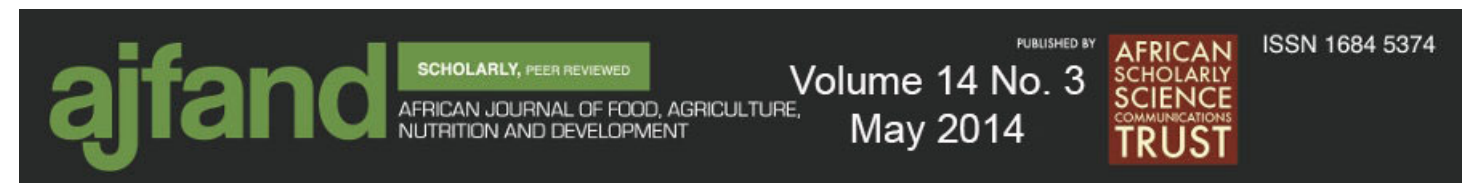

\title{
COMPARISON OF TITHONIA (TITHONIA DIVERSIFOLIA) GREEN MANURE, POULTRY MANURE AND INORGANIC SOURCES OF NITROGEN IN THE GROWTH OF KALES (BRASSICAE OLERACEAE) IN NYERI COUNTY, KENYA
}

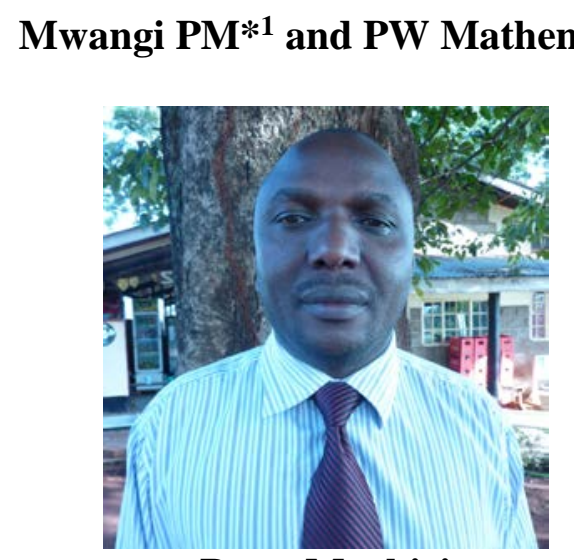

Peter Muchiri

${ }^{*}$ Corresponding author email: mwangipmm@yahoo.com.

${ }^{1}$ Department of Integrated Sciences. St Marks Teachers' Training College - Kigari, Embu Kenya

${ }^{2}$ School of Agriculture and Biotechnology. Karatina University College, Karatina Kenya 


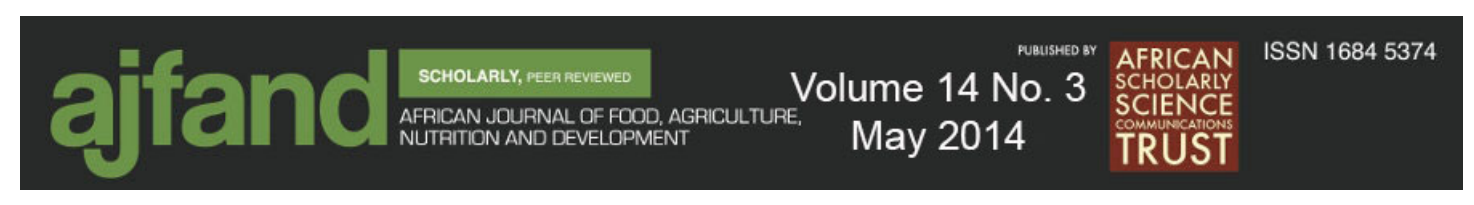

\begin{abstract}
Production of vegetables in Nyeri County (Central Kenya) is greatly hampered by failure of farmers to use fertilizers. This is partly because of the relative high cost of the fertilizers. Tithonia green manure may provide a suitable alternative to the conventional inorganic sources of nitrogen. However, there is little information on its potential benefit especially in the growing of kales, (Brasicae oleraceace). Kales were grown on two experimental sites to compare tithonia green manure, poultry manure and other inorganic sources of nitrogen, namely calcium ammonium nitrate (CAN), urea and ammonium sulphate nitrate (ASN). The fertilizer treatments were applied in three levels of; $30 \mathrm{~kg}$ of N/ha, $60 \mathrm{~kg}$ of N/ha and unfertilized control, from inorganic and equivalent of organic sources. Except for tithonia green manure, all the other treatments were administered at the time of transplanting. The experiment was a Completely Randomized Block Design, with five treatments in three levels, replicated three times on each site, and each site being a replica. Individual plots measured $4 \mathrm{~m} \mathrm{x}$ $3 \mathrm{~m}$ at inter-plant and inter-row spacing of $60 \mathrm{~cm}$ x $60 \mathrm{~cm}$, respectively. The inter-plot spacing was $50 \mathrm{~cm}$ and inter-block spacing was $100 \mathrm{~cm}$. The fresh weight of kales was compared for all the treatments as well as the control. The data collected were subjected to F-test using SPSS proprietary computer software (Version 12.00). Treatment means found to be significantly different from each other were separated by Duncan Multiple Range Test at 5\% confidence level. The results indicated that tithonia green manure applied at $60 \mathrm{~kg}$ of $\mathrm{N} / \mathrm{ha}$ or $9 \mathrm{t} / \mathrm{ha}$ equivalent of dry matter, produced the highest fresh weight of kales followed by calcium ammonium nitrate applied at the same rates. The difference was significant and higher by an average of $7.65 \%$ from the two experimental sites. Nevertheless, tithonia green manure was not easily available during the traditional planting season in the region. Further research is required to explore the possibility of applying it in mixture with poultry manure because as observed, many smallholder mixed farmers also keep poultry which could be a source of poultry manure. Undoubtly, organic fertilizers complement inorganic fertilizers.
\end{abstract}

Key words: Nitrogen, yields, Tithonia, plant nutrients 


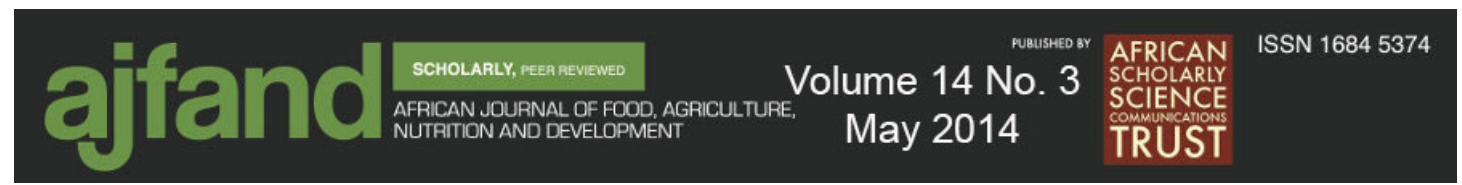

\section{INTRODUCTION}

Low fertilizer use is one of the major problems facing smallholder mixed farmers in Nyeri County. The county is densely populated, presumably because of its favourable climate. Crop production by the smallholder mixed farmers has remained quite low over the years. Failure to use fertilizers at the recommended rates or not to use them altogether may be one of the reasons for the low crop productivity. The situation is exacerbated by continued land subdivision which has not favored the traditional fallow farming system. Continued cultivation on the same parcel of land, season after season without effective efforts to rejuvenate the soils, has led to soil degradation and the inevitable loss in soil fertility [1, 2]. Because of that, food security for the majority of the smallholder mixed farmers has remained elusive with many households registering high poverty levels.

Efforts by extension officers to sensitize farmers on the use of fertilizers have not been very successful. Although the farmers are receptive, they lack the necessary purchasing power. On its part the Government of Kenya occasionally provides fertilizer subsidies. However, the subsidies may not be availed at the opportune time and distribution points are still far apart. A good number of farmers have tried using farm-yard manure but the results have not been promising. This is partly because their small farm holdings lack the capacity to sustain many livestock which would in turn generate adequate manure. Moreover, the farm-yard manure is low in essential nutrients and takes a lot of time to decompose and release nutrients into the soil.

Efforts to use various sources of green manure in order to address soil fertility problems are widely documented. These studies have included the possible use of tithonia as a source of plant nutrients, supply of organic matter and in ameliorating soil acidity. The basis for that has been a unique characteristic found in tithonia; it has nutrients averaging 3.5\%, nitrogen $(\mathrm{N}), 0.37 \%$, phosphorus $(\mathrm{P})$ and $4.1 \%$ potassium (K) on dry matter basis [3]. Thus, tithonia green manure was identified as a nutrient source of lowland rice, as an effective source of nutrients for maize in Western Kenya, and in the Central highlands of Kenya [3, 4, 5, 6, 7, 8]. Similar results have been obtained on good and poor soils in Mucwa, Meru County, Kenya [1, 2]. The good soils were based in terms of soil $\mathrm{pH}$, total soil carbon and available $\mathrm{P}$ [2]. Additionally, application of tithonia leaves at the rate of 1.5 tonnes per hectare produced maize grain yields that were $39 \%$ more than unfertilized control at Bembeke Zambia [9]. Besides registering high maize yields, tithonia green manure has been recognized as having the potential of improving soil fertility [10,11]. It led to increased soil nitrogen $(\mathrm{N})$,phosphorus $(\mathrm{P})$, potassium $(\mathrm{K})$, calcium $(\mathrm{Ca})$, magnesium ( $\mathrm{Mg}$ ) and zinc ( $\mathrm{Zn})$ cation exchange capacity and soil organic matter in Ibadan Nigeria and calcium (Ca), potassium $(\mathrm{K})$, sodium $(\mathrm{Na})$ and phosphorus $(\mathrm{P})$ in the topsoil and copper $(\mathrm{Cu})$, iron $(\mathrm{Fe})$ and zinc $(\mathrm{Zn})$ on amended soils in South Western Nigeria [12, 13]. Tithonia green manure treatments produced higher crop yield than inorganic fertilizers [2, 14, 15, 16]. However, in a related study, sole application of tithonia green manure registered the lowest maize grain and stover yields compared to a combination of farm-yard manure, DAP fertilizer and CAN; 


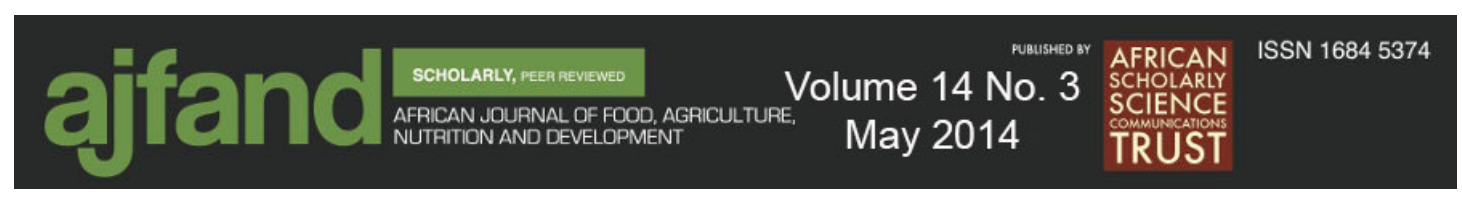

tithonia green manure and tithonia tea (foliar spray); farm-yard manure and tithonia tea (foliar spray), both at Ngata and Gachoka sites [17]. In spite of that, sole application of tithonia green manure had the highest nutrient balance for $\mathrm{N}$ and $\mathrm{K}$ [17].

Studies done in Western Kenya to compare the rate of biomass and nutrient accumulation among Tithonia diversifolia, Tephrosia vogelii and maize, proved that tithonia had the highest rates of accumulation of both the biomass and nutrient [18]. Nutrient concentration from tithonia tended to be more in naturalized hedges than agricultural fields and lower in older leaves than in young ones [19]. A comparison of older and green leaves collected from plants in ten locations in Western Kenya revealed a mean nitrogen concentration of $1.1 \%$ for senescence leaves as compared to $3.2 \%$ for young green leaves. The tithonia green manure was found to decompose rapidly upon being incorporated into the soil providing an effective source of $\mathrm{N}, \mathrm{P}$ and $\mathrm{K}$ for crops [3]. A half-life of one week for nitrogen and two weeks for phosphorus release was observed [6]. The high nitrogen content coupled with a rapid decomposition of the tithonia green manure makes it an attractive source of nitrogen in the soil. The presence of nitrogen in the soil has been found to enhance the uptake of other soil plant nutrients, notably phosphorus. Tithonia green manure enhanced $\mathrm{P}$ availability and uptake by maize resulting in an improvement on stover and grain yields [11]. Besides, tithonia green manure contains substantial amounts of available quantities of $\mathrm{K}$ and $\mathrm{P}$ that are comparable to inorganic sources, and upon decomposition, it adds organic matter into the soil which improves water holding capacity of the soil, reduces leaching, enhances P-sorption and ameliorates soil acidity $[4,11,20,21]$.

Despite the wide knowledge on tithonia green manure, it has not been adequately investigated in the growing of kales. Its use as an alternative source of nitrogen in the growing of kales has not been carried out. The specific quantities that can be applied either to supplement or completely replace the other inorganic sources of nitrogen are not available. No information is available to show how it compares with the other sources of nitrogen in Nyeri County. Without that information, it would be difficult to make any substantive recommendations on its usage. The objective of the study was to test the hypothesis that the yields of kales grown after treatment with tithonia green manure at half and full recommendation rates of $30 \mathrm{~kg}$ of N/ha and $60 \mathrm{~kg}$ of N/ha respectively, would be significantly high in comparison to those treated with poultry manure, calcium ammonium nitrate, ammonium sulphate nitrate and urea in similar rates. An observation made during the study showed that a majority of the smallholder farmers kept poultry, hence it was considered necessary to incorporate poultry manure as a treatment. 


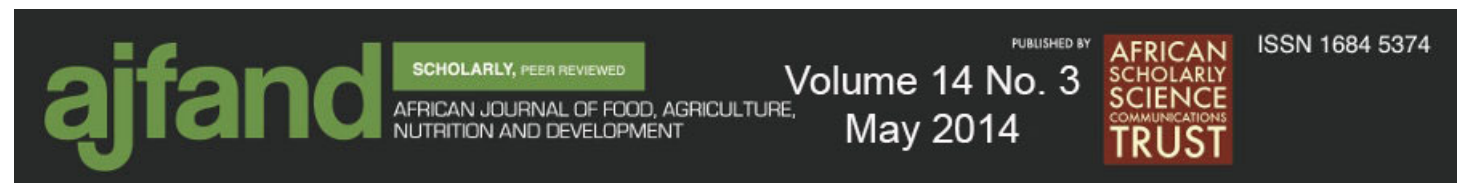

\section{MATERIALS AND METHODS}

\section{Study sites}

The experiment was set up in two different locations in Nyeri County in March 2009. Site A was at Wambugu Farmers Training Center while site B was at Kagumo Teachers Training College. Both sites are in the agro-climatic zone UM 2, the main coffee zone. The two sites were chosen as they would allow for the collection of more data. Besides, soil fertility was slightly different on the two sites. On both sites, there is $66 \%$ reliability of rainfall during the first rainy season (March-May) and the second rainfall season (October-December). Rainfall in the two seasons is between 1600 $1800 \mathrm{~mm}$ and $400-460 \mathrm{~mm}$ respectively. The dominant soils are fertile, well drained deep Ando-humic Nitisols and humic Andosols. The soils have however become exhausted because of inadequate manure and fertilizer applications.

As a result of continued land subdivision that has been accentuated by the high population growth in Nyeri County, the average household farm size has decreased from 2.8 ha in 1978 to 1.09 ha in 2004 [22]. There is intense smallholder mixed farming that involves dairy farming, poultry keeping, and growing of vegetables under green houses, cash crops growing and rearing of rabbits. Coffee is the dominant crop followed by tea, bananas, macadamia, avocado and mangoes in order of economic importance. The use of certified maize seeds and application of inorganic fertilizers is quite low, averaging $10 \%$ [23].

\section{Experimental design}

The experiment was a Complete Randomized Block Design with three replicates. There were five treatments in three levels of: and $0 \mathrm{~kg}$ of N/ha. The treatments were tithonia green manure, poultry manure, ammonium sulphate nitrate, calcium ammonium nitrate and urea. For tithonia green manure and poultry manure the amounts of dry matter supplied to give equivalent amounts of $60 \mathrm{~kg}$ of N/ha and $30 \mathrm{~kg}$ of N/ha were: $8.6 \mathrm{t} \mathrm{DM} / \mathrm{ha}$ and $4.3 \mathrm{t}$ of $\mathrm{DM} /$ ha of tithonia and; $2.8 \mathrm{t}$ of $\mathrm{DM} / \mathrm{ha}$ and $1.4 \mathrm{t}$ of DM/ha of poultry manure, respectively. The plots measured 4 by 3 metres with an inter-plot spacing of $50 \mathrm{~cm}$.

\section{Soil sampling}

Prior to setting up the experiment and at the end of the cropping season, soils were sampled and analyzed to determine nutrient status. Soil sampling before planting was carried out using the transverse method. After harvest three plants of each treatment were randomly selected, uprooted and soils beneath collected for analysis. Soils were collected at intervals of $10 \mathrm{~cm}$ and from a depth of 0-30 cm for top soil and 30-60 cm for subsoil, respectively. Composite samples were prepared for each type of soil. Nitrogen status was determined according to the Kjeldahl method and phosphorus $\left(\mathrm{P}_{2} \mathrm{O}_{5}\right)$ status by double acid extraction followed by Melisch colorimetric method using ultra violet light spectrophotometer. Potassium analysis was by double acid extraction and then, analyses by frame photometer [24, 25].The analysis were carried out at Kenya Agricultural Research Institute, Embu. The analyses are given in (Tables 1 and 2). 


\section{Transplanting}

Seedlings were transplanted five weeks after sowing. Healthy and vigorously growing seedlings were selected from the nursery beds. About four hours before transplanting, the nursery beds were watered to allow the lifting of seedlings with soil clods adhering to the roots.

\section{Treatments}

Treatments were solely applied in single doses in three levels. Except for tithonia green manure, all the other treatments were administered at the time of transplanting. Fresh tithonia green manure was incorporated $15 \mathrm{~cm}$ deep into the planting holes two weeks before transplanting. In order to overcome the effects of phosphorus deficiency in the soil, triple super phosphate was applied at the rate of $60 \mathrm{~kg} / \mathrm{ha}$ for all the treatments. No information was available to indicate how long it takes for poultry manure to decompose and release nitrogen into the soil. Therefore, the researcher opted not to incorporate it into the soil before transplanting.

Conventionally, these inorganic fertilizers are applied in splits as topdressing fertilizers. However, they were applied as indicated because the seedlings were already in the leaf stage and kales being a short season crop, would not benefit much from fertilizers applied in splits. Moreover, it was a way of controlling variables. Tithonia was sourced from Kabirui-ini forest, along the Nyeri-Nyahururu road and along farmers' hedges in Gaki location of Tetu constituency.

Poultry manure was collected from Kagumo Teachers College poultry unit while the inorganic nitrogenous fertilizers were purchased from agro-vet shops in Nyeri town. Calculations were done based on dry matter (for tithonia manure) and on dry samples for the other treatments to determine the actual amount of green manure for each treatment needed to supply an equivalent of $30 \mathrm{~kg}$ of $\mathrm{N} / \mathrm{ha}$ and $60 \mathrm{~kg}$ of $\mathrm{N} / \mathrm{ha}$ respectively (Table 3).

\section{Harvesting}

Twelve plants were selected within the effective plot from which the fresh weights of the leafy portion of kales were taken. Fresh weight was considered more appropriate than dry weight because the produce is ordinarily harvested, utilized or sold in this form. Harvesting started fifty days from the day of transplanting. From individual plots, there were four harvests at intervals of seven days comprising of three separate plants for each harvest. Later, these weights were compounded to constitute the weight for each treatment. This approach was adopted to accommodate the varying harvesting period in the region.

\section{Data collection and Analysis}

Height of plants, number of leaves and approximate leaf surface area for each treatment were taken at regular intervals. Data collected on fresh weight of kales were subjected to the F-test using SPSS computer software (version 12.0). Where the F-test 


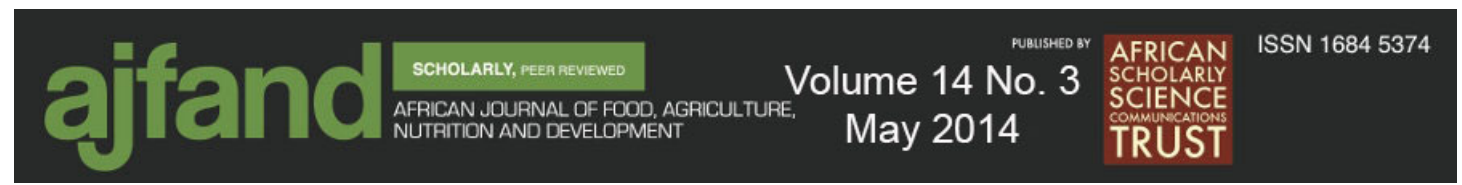

showed a significant difference between treatment means, the means were separated using Duncan Multiple Range Test at $(\mathrm{P}<0.05)$.

\section{RESULTS}

The results for soil analysis prior to setting up the experiment and after harvesting are as shown in Table 1 and Table 2, respectively.

The soils at site A were slightly more fertile than those at site B as indicated by the percent (nitrogen, phosphorus and potassium). The soils were also less acid.

The treatments had varying effects on the growth of plants as indicated by the average number of leaves (Fig. 1).

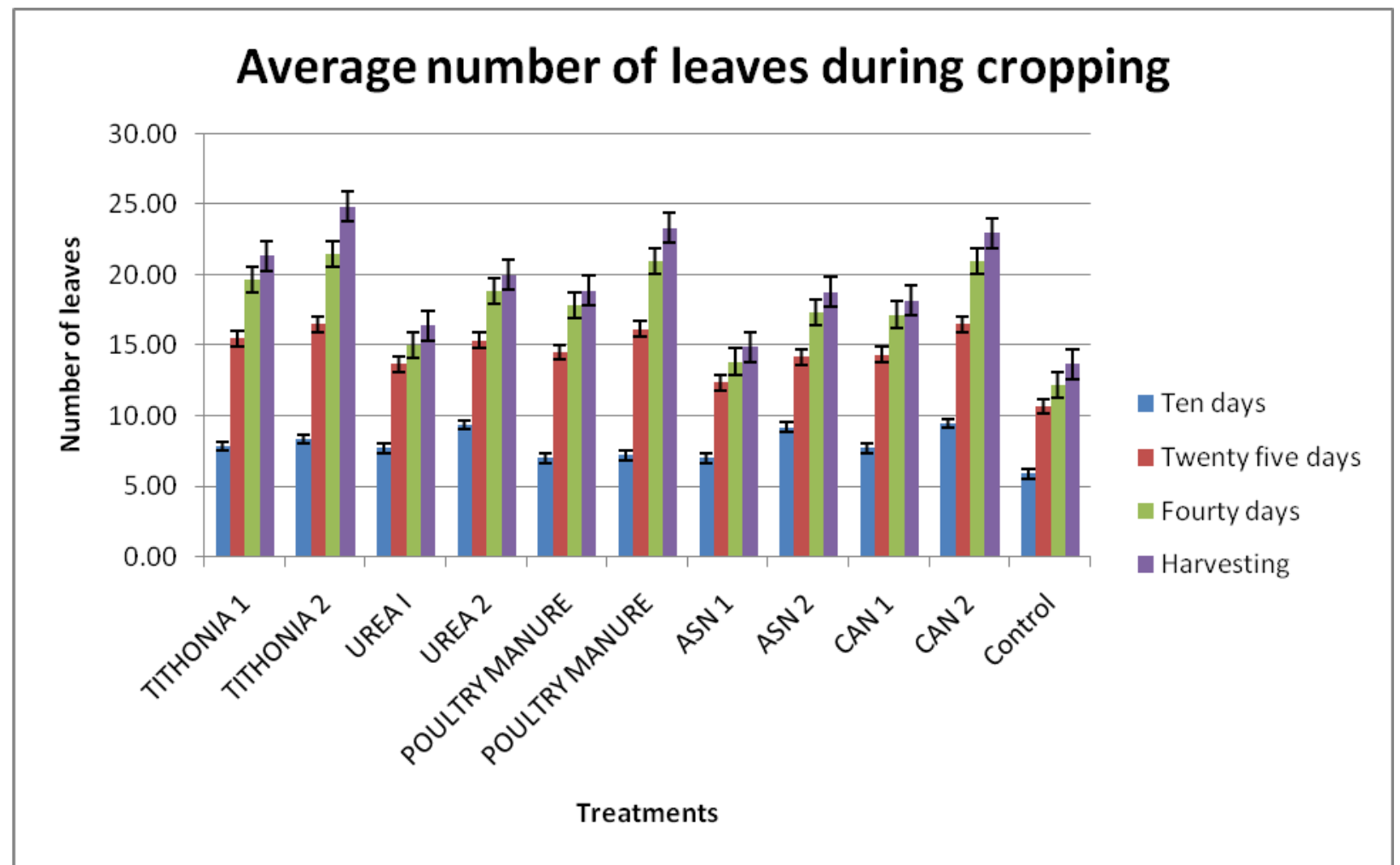

\section{Figure 1: Average number of leaves during cropping. 1 and 2 refers to application rates of $30 \mathrm{~kg}$ of $\mathrm{N} / \mathrm{ha}$ and $60 \mathrm{~kg}$ of $\mathrm{N} / \mathrm{ha}$, respectively.}

The relationship between the height of plants and the other two parameters was not succinct but plants that were generally tall also had greater number of leaves and larger surface area of leaves. However, there was a positive correlation between the number of leaves and surface area of leaves for each treatment which determined the fresh weight of kales. 


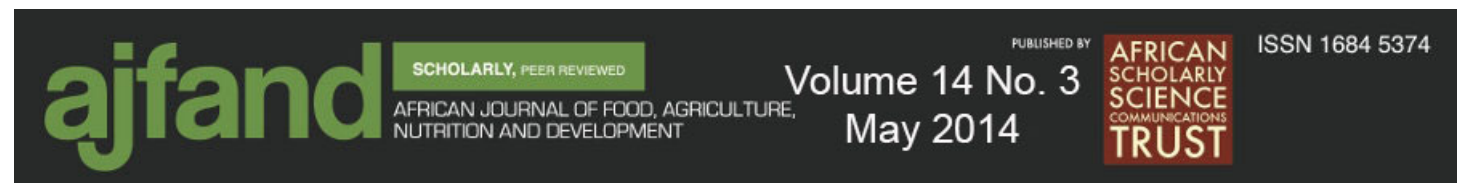

\section{DISCUSSION}

During the early stages of crop growth, CAN, UREA and ASN fertilizers applied at the rates of $60 \mathrm{~kg}$ of $\mathrm{N} / \mathrm{ha}$ had the greatest positive impact on crop growth as indicated by high number of leaves, greater height and leaf surface area of plants, indicating vigorous early growth. The unfertilized control showed the least response based on the three parameters. The trend in crop growth as exemplified by number of leaves and the surface area of the leaves was as shown in figures 1 and 2.

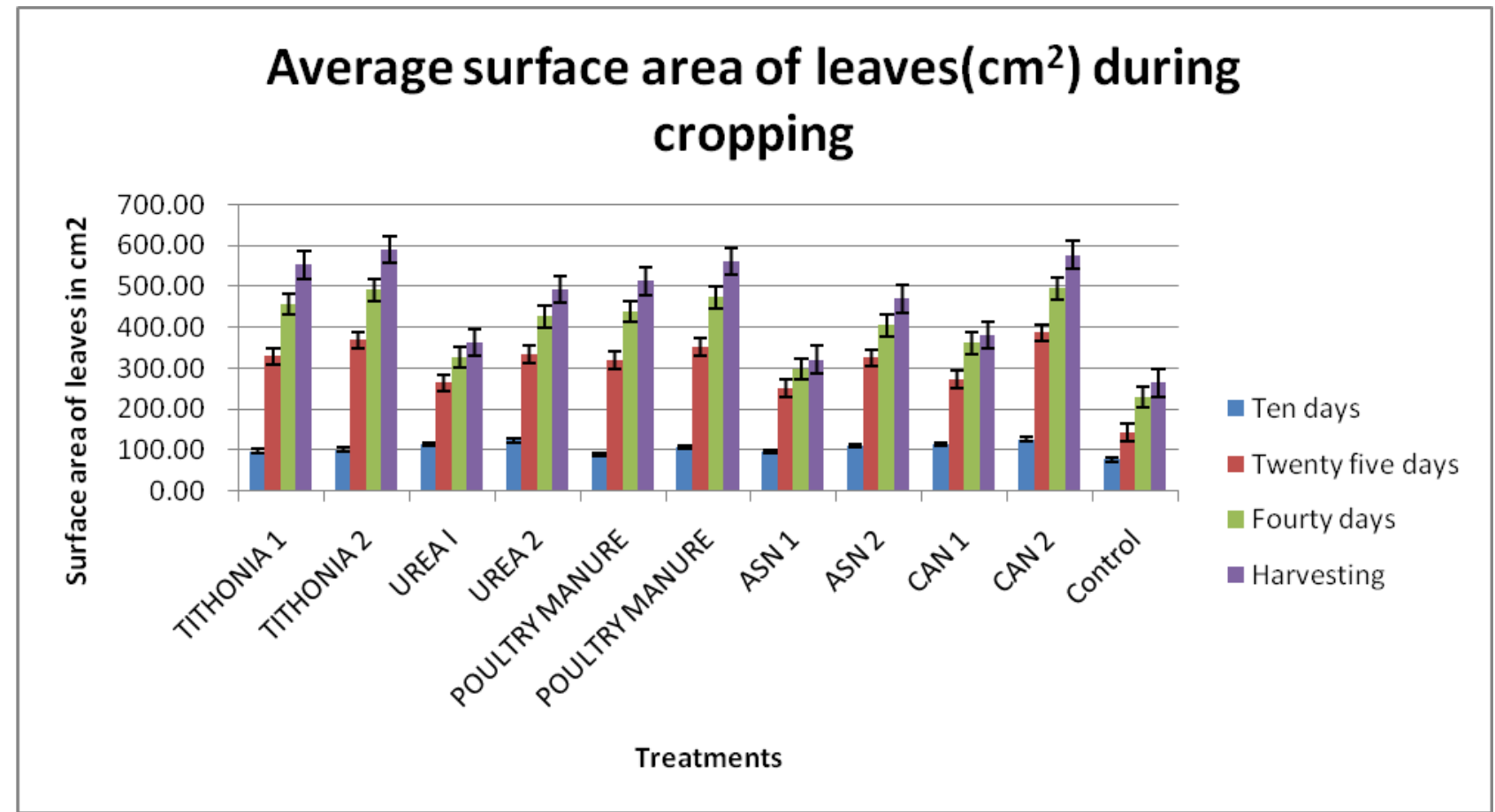

\section{Figure 2: Average surface area of leaves during cropping. 1 and 2 refers to applications of $30 \mathrm{~kg}$ of N/ha $60 \mathrm{~kg}$ of N/ha, respectively.}

This trend in results could be explained by amount of nitrogen, ease of availability of nitrogen, nitrogen losses due to leaching and volatilization and availability of other nutrients that contribute to plant nutrition. For any particular treatment, plants supplied with the higher amounts of $60 \mathrm{~kg}$ of N/ha registered higher crop growth than those treated with a lower level of $30 \mathrm{~kg}$ of $\mathrm{N} / \mathrm{ha}$. This was due to the relative concentration of the nitrogen available to plants, with higher application rates providing an enhanced availability of nitrogen.

Calcium ammonium nitrate fertilizer (CAN) supplies nitrogen to plants in form of nitrates. The nitrate is highly mobile in the soil and reaches the plant roots quickly where it is easily absorbed [26].That could account for the faster response of plants after treatment with CAN fertilizer. Ammonium sulphate nitrate fertilizer (ASN) avails nitrogen in form of ammonium and nitrate [26].The ammonium ion is less mobile in the soil than the nitrate ion. Plant roots thus need to grow towards it. While in the soil, most of the ammonium ion is transformed into nitrate by soil microbes in 


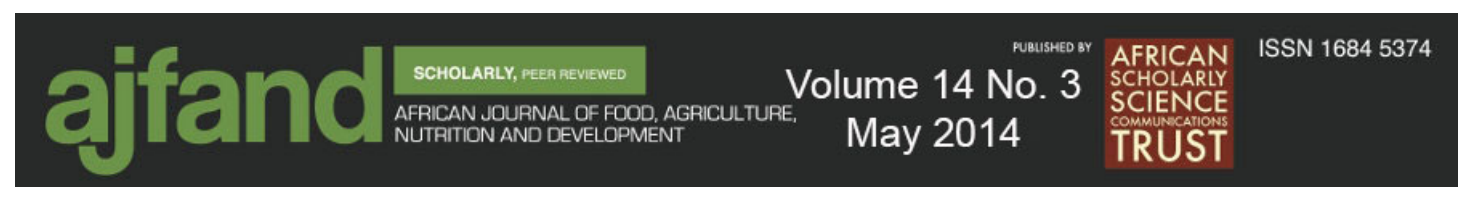

the process of nitrification, a process that may take one week to several weeks depending on the population of soil microbes and soil temperature [26]. So for plants to benefit from ASN fertilizer, the rate at which the plant roots grow towards the ammonium ion and the rate of nitrification are important determinants. Both way, there is considerable time for response to applied fertilizer to take effect, and this partly explains the relatively slower pace of plants response to ASN fertilizer compared to CAN fertilizer.

Urea fertilizer supplies nitrogen in form of ammonium [26]. Urea needs first to be hydrolyzed in the soil by soil microbes to ammonium [27]. The process may take place between a day and a week depending on soil temperature and soil moisture. Results from this experiment indicate that plants' response to nitrogen sourced from urea was higher than plants response to ASN fertilizer although they both supply nitrogen in form of ammonium. That could possibly be due to differences in the rates of nitrification in ASN vis-a-vis hydrolysis in urea, with the results favoring the latter reaction. The lower nitrogen efficiency observed with urea fertilizer could further be explained by nitrogen losses through volatilization. The ammonium generated by hydrolysis of urea shifts the natural balance between $\mathrm{NH}_{4}{ }^{+}$and $\mathrm{NH}_{3}$ to the latter form, resulting in volatilization losses [26, 27, 28].

Tithonia green manure supplies nitrogen in form of ammonium [3]. It may take approximately two to three weeks before the green manure is degraded to release the nitrogen, a process that is influenced by temperature, soil moisture, population of soil microbes and efficiency of incorporation. Results from this study indicate that during the first ten days, the response of plants treated with tithonia green manure was less than inorganic fertilizers supplied at the same rates of $60 \mathrm{~kg}$ of N/ha. This could be attributed to its incomplete decomposition and slow release of nitrogen into the soil. However, as time passed by, the dynamics changed and at the rate of $60 \mathrm{~kg}$ of N/ha tithonia green manure gradually outperformed most of the other treatments. At harvesting time tithonia gave a better performance than CAN fertilizer, possibly due to nitrogen losses through leaching in CAN fertilizer as indicated by the increase in nitrogen content in the subsoil layer (Table 2). In addition, and as supported by other studies done elsewhere, tithonia green manure contained other plant nutrients that contributed to plant nutrition [2, 3, 4, 5, 13, 14, 16, 29]. Moreover, it was observed to be effective in ameliorating soil acidity and thereby enhancing availability of nutrients $[4,11,30]$.

Poultry manure supplies nitrogen in form of ammonium ion. The process depends on the amount of manure incorporated into the soil, soil temperatures and amount of soil microbes [31]. During the first ten days of transplanting, supposedly there was considerable amount of nitrogen available to plants from poultry manure because the number of leaves, height of plants and leaf surface area was greater than for the unfertilized control. Compared to tithonia green manure applied at either of the two levels, tithonia gave a better performance than poultry manure, partly because it had more time to decompose and release nitrogen to the soil. As crop growth progressed, plants treated with poultry manure at the same rate of $30 \mathrm{~kg}$ of N/ha had a better 


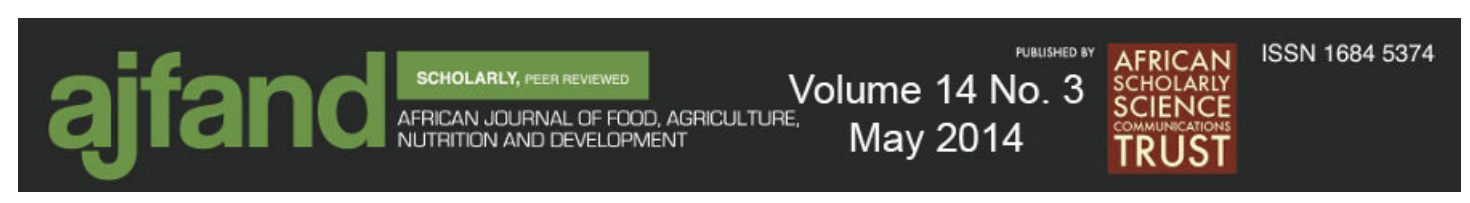

performance compared to Urea, ASN fertilizer and CAN fertilizers. This was perhaps an indication that it had sufficiently decomposed to an extent of availing more nitrogen than the inorganic sources. Additionally, due to its organic component, it had retained and subsequently supplied nitrogen to the plants while the inorganic fertilizers might have lost it through leaching.

At the time of harvesting, treatments that favored an increase in the three parameters had a positive impact on the fresh weight of kales (Table 5). Green plants, like kales make their own food mainly in the leaves by the process of photosynthesis [32]. Consequently, plants that exhibited higher number of leaves and leaf surface area had more exposure to sunlight, synthesizing more food, which in turn translated to high fresh weight.

\section{CONCLUSION AND RECOMMENDATIONS}

Even though results from this study have proved that tithonia plays an important role in improving soil productivity, its availability is still scarce and hence this study recommends the government to set aside suitable land for the production of this plant for the purpose of complementing inorganic fertilizers. For ease of transportation and application, it can be processed into powdered pellets. In addition, there should be more sensitization on the use of tithonia because even where it is found growing along the hedges, it has not been adequately utilized. Poultry farmers should be encouraged to use poultry manure in their farms. These interventions may save the farmers from the high cost of inorganic fertilizers, enhance food security and alleviate poverty in Nyeri County.

\section{ACKNOWLEDGEMENTS}

The research team would like to offer their acknowledgement to the farm managers of Kagumo Teachers College and Wambugu Farmers Training Centre, Mr.Erustus Kinyua and Mr. John Kioko respectively, for their support in setting up the trials, providing materials and support on the experimental sites and finally to $\mathrm{Mr}$. Humphrey Gachomo of Kimathi University for proof reading and correcting grammatical errors the whole document. 


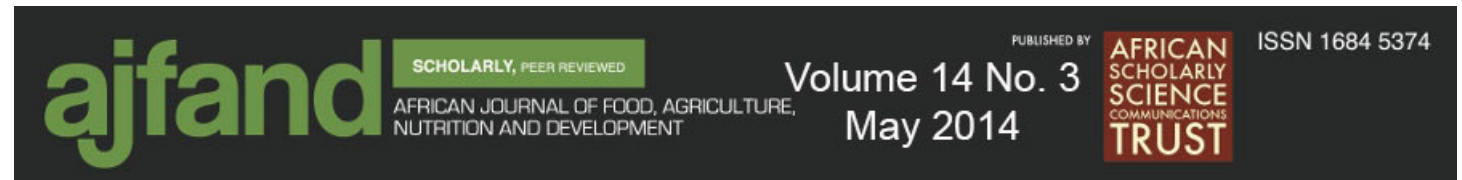

Table 1: Percent (N, $\mathrm{P}_{2} \mathrm{O}_{5}, \mathrm{~K}_{2} \mathrm{O}$ ) and soil reaction ( $\left.\mathrm{PH}\right)$ from the research sites before transplanting

\begin{tabular}{|l|l|l|l|l|}
\hline & & Percent & & \\
& Percent N & $\mathbf{P}_{\mathbf{2 0}}$ & Percent $\mathbf{K}_{2} \mathbf{0}$ & $\mathbf{p H}$ \\
\hline Kagumo Topsoil & 0.25 & 5.62 & 0.61 & 5.2 \\
\hline Kagumo Subsoil & 0.18 & 5.42 & 0.53 & 5.0 \\
\hline Wambugu Topsoil & 0.31 & 5.78 & 0.76 & 5.4 \\
\hline Wambugu Subsoil & 0.19 & 5.51 & 0.56 & 5.7 \\
\hline
\end{tabular}




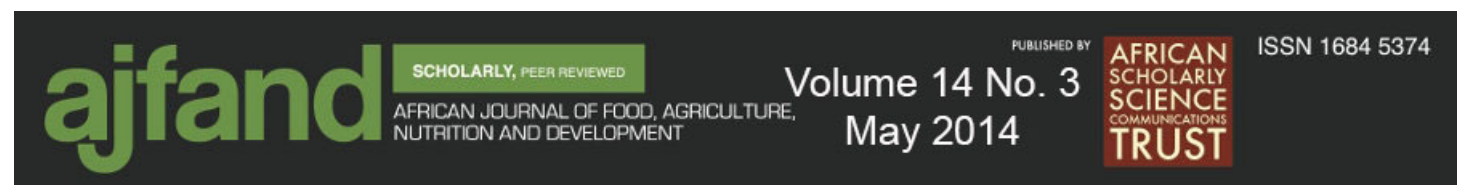

Table 2: Percent $\left(\mathrm{N}, \mathrm{P}_{2} \mathrm{O}_{5}, \mathrm{~K}_{2} \mathrm{O}\right)$ and soil reaction $\mathrm{pH}$ from site $A$ after harvest

\begin{tabular}{|c|c|c|c|c|c|c|c|c|}
\hline & \multicolumn{2}{|c|}{ Percent N } & \multicolumn{2}{|c|}{ Percent $\mathrm{P}_{2} \mathrm{O}_{5}$} & \multicolumn{2}{|c|}{ Percent $\mathrm{K}_{2} \mathrm{O}$} & \multicolumn{2}{|l|}{ pH } \\
\hline & Level 1 & Level 2 & Level 1 & Level 2 & Level 1 & Level 2 & Level 1 & Level 2 \\
\hline Tithonia1 TS & 0.41 & 0.47 & 5.80 & 5.82 & 0.71 & 0.73 & 6.9 & 7.0 \\
\hline Tithonia1 SS & 0.20 & 0.22 & 5.76 & 5.79 & 0.40 & 0.46 & 6.7 & 6.8 \\
\hline Tithonia2 TS & 0.42 & 0.48 & 5.84 & 5.86 & 0.74 & 0.75 & 6.8 & 7.1 \\
\hline Tithonia2 SS & 0.21 & 0.24 & 5.81 & 5.82 & 0.42 & 0.45 & 6.6 & 6.7 \\
\hline Urea 1 TS & 0.22 & 0.23 & 5.71 & 5.72 & 0.56 & 0.57 & 5.2 & 5.1 \\
\hline Urea 1 SS & 0.23 & 0.25 & 5.71 & 5.72 & 0.40 & 0.41 & 5.2 & 5.0 \\
\hline Urea 2 TS & 0.23 & 0.24 & 5.72 & 5.73 & 0.59 & 0.60 & 5.2 & 5.2 \\
\hline Urea 2 SS & 0.25 & 0.27 & 5.73 & 5.74 & 0.42 & 0.45 & 5.4 & 6.5 \\
\hline Poultry 1 TS & 0.32 & 0.38 & 5.73 & 5.74 & 0.66 & 0.67 & 6.3 & 6.4 \\
\hline Poultry 1 SS & 0.20 & 0.22 & 5.73 & 5.79 & 0.53 & 0.55 & 6.0 & 6.8 \\
\hline Poultry 2 TS & 0.38 & 0.43 & 5.74 & 5.80 & 0.68 & 0.70 & 6.6 & 6.5 \\
\hline Poultry2 SS & 0.21 & 0.23 & 5.79 & 5.81 & 0.54 & 0.55 & 6.2 & 5.0 \\
\hline ASN 1 TS & 0.18 & 0.21 & 5.70 & 5.72 & 0.61 & 0.62 & 5.2 & 5.3 \\
\hline ASN 1 SS & 0.19 & 0.20 & 5.72 & 5.73 & 0.49 & 0.52 & 5.4 & 4.9 \\
\hline ASN 2 TS & 0.20 & 0.22 & 5.73 & 5.73 & 0.63 & 0.65 & 5.0 & 5.1 \\
\hline ASN 2 SS & 0.24 & 0.26 & 5.72 & 5.74 & 0.51 & 0.53 & 5.3 & 5.2 \\
\hline CAN 1 TS & 0.23 & 0.27 & 5.76 & 5.65 & 0.61 & 0.62 & 5.3 & 5.6 \\
\hline CAN 1 SS & 0.36 & 0.42 & 5.62 & 5.73 & 0.46 & 0.48 & 5.6 & 5.5 \\
\hline CAN 2 TS & 0.28 & 0.30 & 5.81 & 5.80 & 0.58 & 0.59 & 5.6 & 5.6 \\
\hline CAN 2 SS & 0.41 & 0.48 & 5.53 & 5.53 & 0.42 & 0.45 & 5.6 & 5.5 \\
\hline Control TS & \multicolumn{2}{|c|}{$\frac{1}{0.24}$} & \multicolumn{2}{|c|}{5.56} & \multicolumn{2}{|c|}{0.57} & \multicolumn{2}{|r|}{5.3} \\
\hline Control SS & \multicolumn{2}{|c|}{0.13} & \multicolumn{2}{|c|}{4.48} & \multicolumn{2}{|c|}{0.53} & \multicolumn{2}{|r|}{5.6} \\
\hline
\end{tabular}

TS and SS imply topsoil and subsoil respectively. Levels 1 and 2 refer to applications of $30 \mathrm{~kg}$ of N/ha $60 \mathrm{~kg}$ of N/ha respectively. Poultry implies poultry manure. 


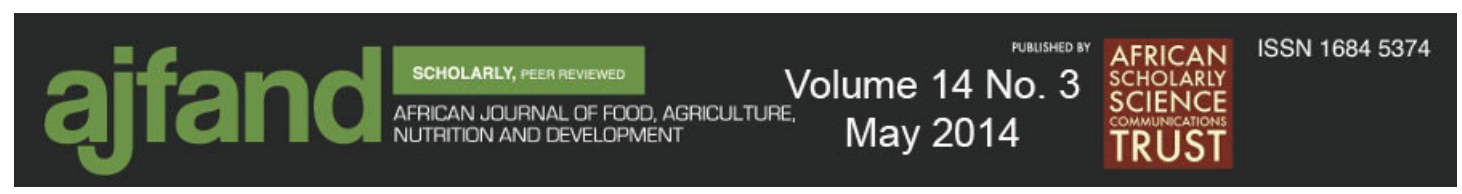

Table 3: The percent nitrogen content of the various treatments per $100 \mathrm{~kg}$ of (dried tithonia leaves, dry poultry manure), CAN, Urea and ASN fertilizers and actual amounts that were applied to supply an equivalent of $30 \mathrm{~kg}$ of $\mathrm{N} / \mathrm{ha}$ and $60 \mathrm{~kg}$ of $\mathrm{N} / \mathrm{ha}$

\begin{tabular}{|c|c|c|c|}
\hline Samples & $\begin{array}{l}\text { Percent } \\
\text { nitrogen } \\
\text { content in kg }\end{array}$ & $\begin{array}{l}\text { Amount applied } \\
\text { (kg) to supply an } \\
\text { equivalent of } \\
30 \mathrm{~kg} \text { of } \mathrm{N} / \mathrm{ha}\end{array}$ & $\begin{array}{l}\text { Amount applied } \\
\text { (kg) to supply an } \\
\text { equivalent of } 60 \mathrm{~kg} \\
\text { of } \mathrm{N} / \mathrm{ha}\end{array}$ \\
\hline $\begin{array}{l}\text { Tithonia green } \\
\text { manure }\end{array}$ & $3.10^{*}$ & 4302.98 & 8605.96 \\
\hline Poultry manure & 2.17 & 1382.49 & 2764.98 \\
\hline $\begin{array}{l}\text { Calcium } \\
\text { ammonium nitrate } \\
\text { (CAN) }\end{array}$ & 27 & 111.11 & 222.22 \\
\hline Urea & 46 & 65.22 & 130.44 \\
\hline $\begin{array}{l}\text { Ammonium } \\
\text { sulphate nitrate } \\
\text { (ASN) }\end{array}$ & 26 & 115.39 & 230.78 \\
\hline
\end{tabular}

${ }^{*}$ The value was based on dry matter content of $22.49 \%$ 


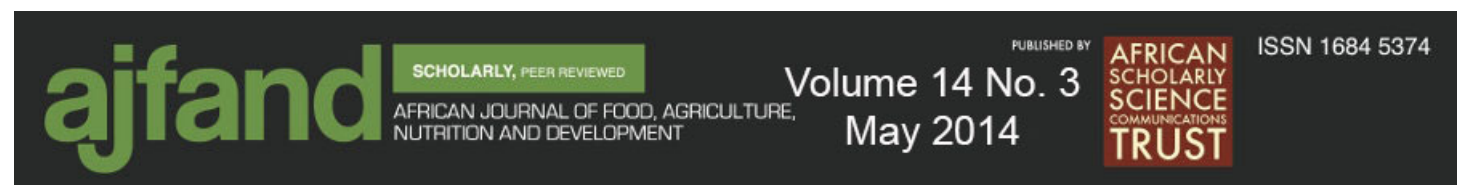

Table 4: Average height of plant in $\mathrm{cm}$ during cropping

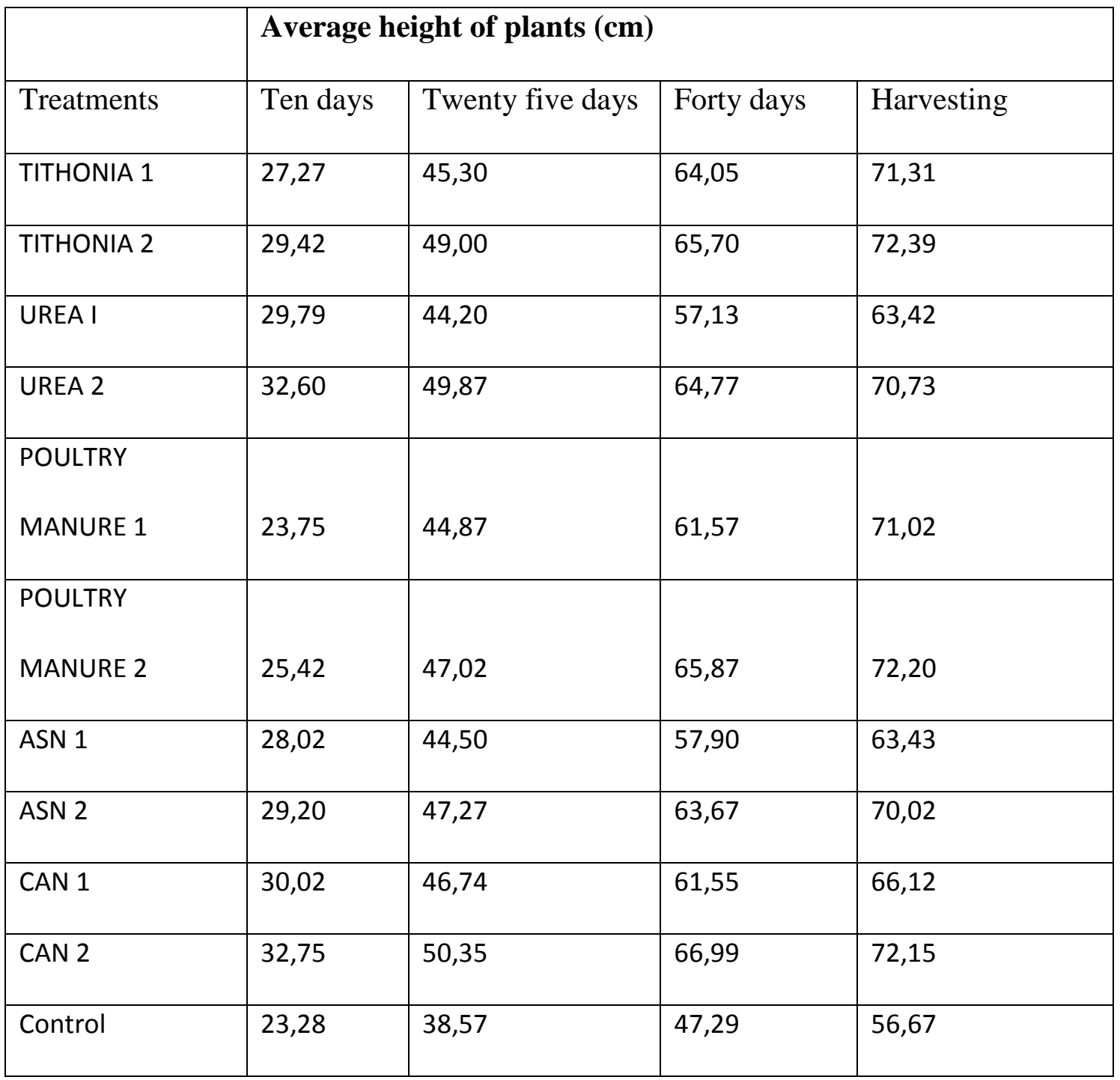

1 and 2 refers applications of $30 \mathrm{~kg}$ of N/ha $60 \mathrm{~kg}$ of N/ha, respectively. 


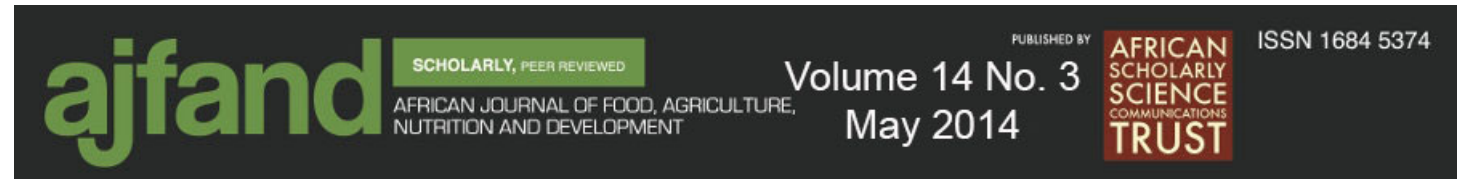

Table 5: Effects of organic and inorganic fertilizer on the mean fresh weight of kales in kilograms

\begin{tabular}{|c|c|c|}
\hline Treatments & $\begin{array}{l}\text { Mean fresh weight of } \\
\text { kales in kg at site A }\end{array}$ & $\begin{array}{l}\text { Mean fresh weight of } \\
\text { kales in kg at site B }\end{array}$ \\
\hline $\begin{array}{l}\text { Tithonia green manure at } \\
60 \mathrm{~kg} \text { of N/ha }\end{array}$ & $5.64^{\mathrm{a}}$ & $5.60^{\mathrm{a}}$ \\
\hline $\begin{array}{l}\text { Calcium ammonium } \\
\text { nitrate at } 60 \mathrm{~kg} \text { of N/ha }\end{array}$ & $5.26^{b}$ & $5.11^{b}$ \\
\hline $\begin{array}{l}\text { Poultry manure at } 60 \mathrm{~kg} \\
\text { of N/ha }\end{array}$ & $4.92^{\mathrm{c}}$ & 4.69 \\
\hline $\begin{array}{l}\text { Tithonia green manure at } \\
30 \mathrm{~kg} \text { of N/ha }\end{array}$ & 4.55 & 4.60 \\
\hline $\begin{array}{l}\text { Poultry manure at } 30 \mathrm{~kg} \\
\text { of N/ha }\end{array}$ & $4.42^{d}$ & $4.38^{\mathrm{c}}$ \\
\hline Urea at $60 \mathrm{~kg}$ of $\mathrm{N} / \mathrm{ha}$ & $3.41^{\mathrm{e}}$ & $3.59^{d}$ \\
\hline $\begin{array}{l}\text { Ammonium sulphate } \\
\text { nitrate at } 60 \mathrm{~kg} \text { of } \mathrm{N} / \mathrm{ha}\end{array}$ & $3.40^{\mathrm{e}}$ & $3.38^{d}$ \\
\hline $\begin{array}{l}\text { Calcium ammonium } \\
\text { nitrate at } 30 \mathrm{~kg} \text { of } \mathrm{N} / \mathrm{ha}\end{array}$ & $3.09^{f}$ & $3.07^{d}$ \\
\hline Urea $30 \mathrm{~kg}$ of N/ha & $2.05^{f}$ & $2.68^{\mathrm{e}}$ \\
\hline $\begin{array}{l}\text { Ammonium sulphate } \\
\text { nitrate at } 30 \mathrm{~kg} \text { of } \mathrm{N} / \mathrm{ha}\end{array}$ & $2.68^{g}$ & $2.36^{f}$ \\
\hline Control & $2.16^{\mathrm{h}}$ & $2.07^{\mathrm{g}}$ \\
\hline
\end{tabular}

* Means followed by the same letters within the column were non significantly different at $(\mathrm{P}<0.05)$ 


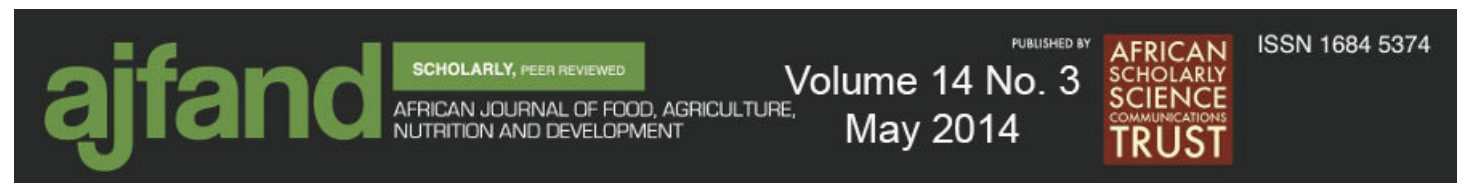

\section{REFERENCES}

1. Mucheru MN, Mugendi DN, Pypers , Mugwe J, Vanlauwe B, Merckx R and JB Kung'u Effects of organic inputs and mineral fertilizer on maize yield in a ferralsol and nitisol soil in Central Kenya. Biomedical and life Sciences. 2011; Part 2: 191-203.

2. Mugendi DN, Mucheru MN, Pieters P, Mugwe J, Kung'u J, Vanlauwe B and $\mathbf{R}$ Merckx Maize productivity as influenced by organic inputs and mineral fertilizer in a Nitisol soil in Meru South District. A paper presented at the $19^{\text {th }}$ World Congress of Soil Science, Soil Solutions for a Changing World $1^{\text {st }}-6^{\text {th }}$ August 2010 Brisbane, Australia. Published on DVD, 2010.

3. Jamal B, Palm CA, Buresh R J, Niang A, Gachengo C, Nziguheha G and B Amadalo Tithonia diversifolia as a green manure for soil fertility improvement in Western Kenya. Agrofor. Syst. 2000; Vol. 49. N0. 2: 201-101.

4. Achieng JO, Ouma G, Odhiambo G and F Muyekho Effect of Tithonia diversifolia (hemsley) and inorganic fertilizers on maize yield on alfisols and ultisols of Western Kenya. Agr Biol J N Am 2010; vol. 1: issue 5 263-265.

5. Mucheru MM, Mugendi DN, Mugwe J and A Bationo Effects of organic and mineral fertilizer inputs on maize yield and soil chemical properties in a maize cropping system in Meru South District, Kenya. Agrofor. Syst. 2007; Vol. 69. N0. 3: 189-197.

6. Mugendi DN, Mucheru MN, Mugwe J, Kung'u J and A Bationo Improving food production using 'best bet' soil fertility technologies in the Central highlands of Kenya. Biomedical and life Sciences. 2007; 345-351.

7. Nagaraj S and BM Nizar Wild sunflower as a source of green manure in rice in the mid- country west zone. Trop. Agric. 1982; 138: 69-78.

8. Nziguheba G1, Merckx R1, Palm CA and P Mutuo Combined use of Tithonia diversifolia and fertilizers for maize production in a phosphorus deficient soil in Western Kenya. Agrofor. Syst. 2002; Vol. 55. N0 3:165-174.

9. Gununga $\mathbf{R}$, Yerokun $\mathbf{O}$ and JD Kumwenda Tithonia diversifolia, an organic source of nitrogen and phosphorus for maize in Malawi. A review. Soil fertility research for maize-based farming systems in Malawi and Zimbabwe 1998; 191-194.

10. Ademiluyi BO and QO Omotoso Comparative evaluation of tithonia diversifolia and NPK fertilizer for soil improvements in maize (Zea mays) production in Edo Ekiti - South - Western Nigeria. Am.-Eurasian J. Sustain. Agric 2007; 1(1): 32-36. 
11. Mulama CN Evaluating the agronomic potential of Tithonia diversifolia prunings in the acid soils of Northern Zambia. A paper presented to the Eastern and Southern Africa regional maize conference, $11^{\text {th }}-15^{\text {th }}$ February 2001: 372-376.

12. Chukwuka KS and OE Omotayo Soil fertility restoration potential of tithonia green manure and water hyacinth compost on nutrient depleted soil in South Western Nigeria using Zea mays as a test crop. Research. Journal of soil Biology. 2009; (1): 20-30.

13. Shokalu AO, Ojo AO, Ezekiel ADT, Akintoye HA and JO Azeez Comparing the use of Tithonia diversifolia and compost as soil amendments for growth and yield of Celosia argentea. New York Science Journal 2010; 3 (6).2-5.

14. Kimetu JM, Mugendi DN, Palm CA, Mutuo PK, Gachengo CN, Bationo A, Nandwa S, and JB Kung'u Nitrogen fertilizer equivalencies of organics of differing quality and optimum combination with inorganic nitrogen source in central Kenya. A review. Nutrient recycling in agro systems 2004; Vol. 68. N0. 2: 127-13.

15. Mucheru MM, Mugendi DN, Mugwe J and A Bationo Effects of organic and mineral fertilizer inputs on maize yield and soil chemical properties in a maize cropping system in Meru South District, Kenya. Agrofor. Syst. 2007; Vol. 69. N0. 3: 189-197.

16. Mugwe J, Mugendi DN, Kung'u J and MN Mucheru Effect of plant biomass, manure and inorganic fertilizers on maize yields in Central highlands of Kenya. Afr. Crop Sci. J. 2007; Vol. 15. N0. 3: 111 - 126.

17. Gachimbi LN, Maina F, Obanyi SN, Onduru DD, Gachini, GN, De J and FN Muchena Evaluation of organic, inorganic fertilizers and tithonia (Tithonia diversifolia) on maize performance in Nitisols of Central Kenya. A farmer field school approach, 2004. INMASP Report No. 2004: Ke-17.

18. Rutunga V, Karanja NK, Gachene CKK and C Palm Biomass production and nutrient accumulation by Tephrosia vogelii (hemsley) a. gray and Tithonia diversifolia fallows during the six-month growth period at Maseno, Western Kenya. Biotechnol Agron Soc Environ 1999; 3 (4): 237-246.

19. George TS, Gregory PJ, Robinson JS, Buresh RJ and BA Jamal Tithonia diversifolia variations in leaf concentrations and implications for biomass transfer. Agrofor. Syst. 2001; Vol. 52: 199 - 205.

20. Olabode OS, Ogunyemi S, Akanbi WB, Adesina GO and PA Babajide Evaluation of tithonia diversifolia (Hemsley) a. gray for Soil Improvement. World J. Agric. Sci. 2007; 3 (4): 503-507. 
21. Kavoo A, Mugendi DN, Muluvi G, Vanlauwe B, Six J, Merckx R, Gentile $\mathbf{R}$ and WMH Kamiri Interaction between resource quality, aggregate turn over, carbon and nitrogen cycling in central highlands of Kenya . Biomedical and life Sciences. 2011; Part 2: 807-816.

22. Jaetzold R, Helmut S, Berthold $\mathbf{H}$ and $\mathbf{C}$ Shisanya National conditions and Farm Management information- $2^{\text {nd }}$ edition. Part B, Central Kenya sub part B, Central Province. Ministry of agriculture- Farm management handbook for Kenya, 2003: vol II.

23. Ministry of Agriculture (Kenya, Annual report 2008.

24. Benton JJ Kjeldahl Method for Nitrogen Determination. Athens, GA: MicroMacro Pub. 1991

25. Melisch A Mass analysis methods for soil fertility evaluation. In: Melisch A Pinkerton A and Kempton. Mass analysis methods for soil fertility evaluation 1962.

26. Mattson N, Leatherwood $\mathbf{R}$ and $\mathbf{C}$ Peters Nitrogen, all forms are not equal. Cornell University cooperative extension news letter. June 2009.

27. Bundy LG How to reduce volatilization losses. Department of soil science news letter. University of Wisconsin, 1988.

28. Schwab GJ and LW Murdock Nitrogen transformation inhibitors and controlled release urea. Extension report. Lexington, KY: University of Kentucky College of Agriculture 2005.

29. Kwesi AK and $\mathbf{P}$ Wakhu AFRENA-ECA annual report. $5^{\text {th }}-8^{\text {th }}$ February 1996.

30. Zwart $\mathbf{P}$ Horticulture matters, $\mathrm{pH}$ and nutrient availability. Ministry of agriculture food and rural affairs news letter, Ontario Canada 2006; vol. 6: Issue 20.

31. Bono $\mathbf{A}$ and $\mathbf{J}$ Janaun The transformation of chicken manure into mineralized organic fertilizer. Journal of Sustainable Science and Management 2006. Vol 1: 58-63.

32. Jacinta A and N Njoroge Longhorn Biology Form 1. Nairobi, 2003: 72-83. 